\title{
AMMONIUM HYDROXIDE EXTRACTS FROM BLACK TEA INHIBIT GROWTH, MIGRATION AND INVASION OF COLON CANCER CELLS
}

\author{
HSIU-CHIN HUANG ${ }^{1,6}$, HSIAO-YU CHEN ${ }^{2}$, CHIA-YANG $\mathrm{CHEN}^{3}$, \\ TANG-LONG SHEN ${ }^{4}$, JOHN HUANG ${ }^{5}$, NENG-YU LIN ${ }^{2}$, SHAO-YIN SUM ${ }^{2}$, \\ MEI-IENG $\mathrm{CHE}^{2}$ and MIN-CHUAN HUANG ${ }^{2,7}$
}

${ }^{1}$ Animal Technology Institute Taiwan Miaoli, Taiwan

${ }^{2}$ Institute of Anatomy and Cell Biology

College of Medicine

${ }^{3}$ Institute of Environmental Health

College of Public Health
${ }^{4}$ Department of Plant Pathology and Microbiology
National Taiwan University
${ }^{5}$ Department of Surgery
National Taiwan University Hospital
Taipei, Taiwan
${ }^{6}$ PRIT Biotech Co., Ltd.
Miaoli, Taiwan

Accepted for Publication January 29, 2007

\begin{abstract}
In this study, the effects of ammonium hydroxide extracts from black tea on colon cancer cells were analyzed. Here we showed that black tea extracts decreased the growth of SW480 and HCT116 cells in a dose-dependent manner. The increase of subG1 population indicated that the black tea extracts induced cancer cell death. In addition, cell migration and invasion were significantly inhibited by the black tea extracts. We also found that tyrosine phosphorylation of focal adhesion kinase and paxillin was decreased in these cells, suggesting that integrin signaling pathways were affected by the extracts. In addition, decreased phosphorylation of extracellular signal-

${ }^{7}$ Corresponding author. Dr. Min-Chuan Huang, Institute of Anatomy and Cell Biology, National Taiwan University College of Medicine, No. 1, Sec. 1 Ren-Ai Road, Taipei 100, Taiwan. TEL: 886-2-23123456, Ext. 8177; FAX: 886-2-23915292; EMAIL: mchuang@ntu.edu.tw
\end{abstract}

Journal of Food Biochemistry 32 (2008) 201-215. All Rights Reserved. 
regulated kinase and increased phosphorylation of p38 and c-Jun N-terminal kinase were observed, indicating that the extracts can modulate mitogenactivated protein kinase (MAPK) signaling pathways. These results suggest that the crude ammonium hydroxide extracts from black tea can significantly inhibit malignant phenotypes of colon cancer cells and that integrin and MAPK signaling pathways could be involved.

\section{PRACTICAL APPLICATIONS}

Ammonium hydroxide extracts of black tea can significantly suppress colon cancer cell growth, migration and invasion in vitro. These findings suggest that the ammonium hydroxide extracts of black tea may be applied for cancer treatment and prevention.

\section{INTRODUCTION}

Colorectal cancer is the third most frequent cancer in the world, with an increasing incidence rate in Asian countries. The general survival rate of colorectal cancer patients does not exceed $40 \%$. In developing countries, the survival rate is even lower. Therefore, it is important to develop novel agents for chemoprevention or therapy of colorectal cancer.

Tea is one of the most popular beverages in the world. During the manufacture of black tea, polyphenols in tea leaves undergo polyphenol oxidase-catalyzed oxidative polymerization, which leads to the formation of bisflavanols, theaflavins (TF), thearubigins and other oligomers (Balentine et al. 1997; Wei et al. 1999; Lambert et al. 2005). TF, about 1-2\% of the solids in water extracts of black tea, contribute to the color and taste of black tea. A substantial portion of the water extracts of black tea represents thearubigins, which have a wide range of molecular weights and are poorly characterized (Haslam 2003).

Black tea extracts have been found to exhibit antioxidative, anticarcinogenic and antimutagenic activities (Isemura et al. 2000; Lambert et al. 2005). These activities are assumed to result from the polyphenols present in black tea, such as TF and thearubigins. TF and thearubigins are the products of oxidation and condensation reactions during fermentation of tea leaves. Several methods have been developed to extract the bioactive materials from black tea. The most commonly used solvents for initial extraction step are boiling water and ethanol (Lin et al. 2003). Then, the polyphenols or tea pigments are obtained by further extractions with a series of organic solvents. Black tea pigments have never been extracted by ammonium hydroxide fol- 
lowed by organic solvents (Hung et al. 2002). Previous studies found that these tea pigments have a protective effect on hydrazine-induced liver injury and exhibit a gastrointestinal enhancement of magnetic resonance imaging (Hung et al. 2002, 2003). However, it remains unknown whether the crude ammonium hydroxide extracts of black tea exhibit any anticancer effects.

Crude extracts from black tea can be obtained in an economical way and suitable for industrial production. Ammonium hydroxide has never been used to extract anticancer components from black tea and can be evaporated during concentration process by speed vacuum. In addition, collecting ammonium hydroxide extracts from black tea provides the industry a method to make use of black tea leaves for development of anticancer drugs after making a tea drink, which is water-extracted. We therefore used ammonium hydroxide as a solvent to extract active ingredients from black tea leaves for suppressing cancer cell growth. In this study, we investigated whether ammonium hydroxide extracts from black tea can inhibit cancer cell growth, migration and invasion, which are phenotypes promoting tumor progression. Here we found that the ammonium hydroxide extracts from black tea can significantly inhibit cancer cell growth, migration and invasion. In addition, our results showed that black tea extracts are able to inhibit tyrosine phosphorylation of focal adhesion kinase (FAK) and paxillin. Furthermore, decreased phosphorylated extracellular signal-regulated kinase (pERK) as well as increased phospho-p38 and phosphorylated c-Jun N-terminal kinase (pJNK) were observed. These results suggest that the crude ammonium hydroxide extracts could block tumor cell progression and that integrin and mitogen-activated protein kinase (MAPK) signaling pathways could be involved.

\section{MATERIALS AND METHODS}

\section{Ammonium Hydroxide Extracts from Black Tea}

Ammonium hydroxide extracts of black tea were provided by the PRIT Biotech Co., Ltd. (Miaoli, Taiwan). Briefly, black tea leaves (100 g) were boiled in $1 \mathrm{~L}$ water. After $10 \mathrm{~min}$, the water was discarded and $10 \mathrm{~L}$ of $2 \%$ ammonium hydroxide were added for $12-16 \mathrm{~h}$. The ammonium hydroxide extracts were filtered through filter papers (ADVENTECH, Tokyo, Japan) and were concentrated to half volume with speed vacuum at 50C. Hydrogen chloride $(5 \mathrm{~N})$ was added and precipitates were formed. The precipitates were lyophilized by Dura-Dry (FTS Systems Inc., New York, NY). The ammonium hydroxide extracts from black tea were dissolved in phosphate-buffered saline for all assays. Meanwhile, similar procedures were performed except omitting tea leaves. The obtained solvent was used to treat cells as a mock (control) treatment. 


\section{Cell Culture and Growth Analysis}

Human colon cancer cell lines HCT116 and SW480 (ATCC) were purchased from the Culture Collection and Research Center (Hsinchu, Taiwan). Both cell lines were maintained with Dulbecco's modified Eagle's medium (DMEM; Biowest, Miami, FL) containing 10\% fetal bovine serum (FBS; Biowest) in humidified tissue culture incubator at $37 \mathrm{C}$, in a $5 \% \mathrm{CO}_{2}$ atmosphere. Cells were seeded in six-well plates at a density of $5 \times 10^{5} 1$ day before the treatment. Cells were replaced with fresh DMEM with 10\% FBS and without FBS (serum-free conditions) and then treated with mock $25 \mu \mathrm{g} / \mathrm{mL}$ $(0.0025 \%)$ or $125 \mu \mathrm{g} / \mathrm{mL}(0.0125 \%)$ black tea extracts. After $48 \mathrm{~h}$, viable cells were counted with a hemocytometer (Reichert Co., Buffalo, NY) by trypan blue exclusion assays.

\section{FLOW CYTOMETRY AND APOPTOSIS ASSAYS}

For cell death analysis, cells were grown to $30 \%$ confluence and treated with mock or $25 \mu \mathrm{g} / \mathrm{mL}$ black tea extracts. After $48 \mathrm{~h}$, cells were fixed with ice-cold $70 \%$ ethanol for $30 \mathrm{~min}$. Cells were then treated with $200 \mu \mathrm{g} / \mathrm{mL}$ RNase A (Promega, Madison, WI) and $50 \mu \mathrm{g} / \mathrm{mL}$ propidium iodide (Sigma, St. Louis, MO) for $30 \mathrm{~min}$ at $37 \mathrm{C}$. The stained cells were analyzed with flow cytometer (BD Biosciences, Franklin Lakes, NJ). For apoptosis assays, cells were stained with Fluorescein isothiocynate conjugated-annexin $\mathrm{V}$ and propidium iodide after treatment with black tea extract. Annexin V-positive and propidium iodide-negative cells were considered as apoptotic cells.

\section{Wound Healing Assays}

Cells were seeded in six-well plates and grown until confluence. Cell culture medium was then replaced with serum-free DMEM or DMEM supplemented with $10 \%$ FBS. Cells were treated with mock $25 \mu \mathrm{g} / \mathrm{mL}$ or $125 \mu \mathrm{g} / \mathrm{mL}$ black tea extracts. The monolayer was scratched with a sterile $250 \mu \mathrm{L}$ pipette tip. Migration of cells to the cleared area was inspected under a microscope. Cells were observed for $48 \mathrm{~h}$. Pictures were taken directly at the time of scratching and after scratching at 6-h intervals. Migration rate is presented as migration distance $(\mu \mathrm{m}) /$ time $(\mathrm{h})$.

\section{Matrigel Invasion Assays}

Cell invasion assay was analyzed in a BioCoat Matrigel Invasion Chamber (Becton-Dickinson, Bedford, MA) as previously described (Huang et al. 2006). Briefly, cells $\left(2 \times 10^{5}\right)$ in $500 \mu \mathrm{L}$ DMEM were added to each 
chamber and were allowed to invade the Matrigel for $48 \mathrm{~h}$ in a humidified tissue culture incubator at $37 \mathrm{C}, 5 \% \mathrm{CO}_{2}$ atmosphere. The noninvading cells on the upper surface of the membrane were removed from the chamber and the invading cells on the lower surface of the membrane were fixed with $100 \%$ methanol and then stained with $0.5 \%$ crystal violet (Sigma). After two washes with distilled water, the chambers were allowed to air-dry. Numbers of invading cells per field were counted under a phase contrast microscope. The means \pm standard deviation (SD) were calculated from numbers of five different fields under the microscope.

\section{Immunoprecipitation and Western Blot}

HCT116 cells were treated with mock $25 \mu \mathrm{g} / \mathrm{mL}$ or $50 \mu \mathrm{g} / \mathrm{mL}$ black tea extracts for $48 \mathrm{~h}$. Cells were incubated in lysis buffer containing $20 \mathrm{mM}$ Tris- $\mathrm{HCl}$ ( $\mathrm{pH} 7.4), 150 \mathrm{mM} \mathrm{NaCl}, 1 \mathrm{mM}$ ethylenediaminetetraacetic acid, $1 \%$ Triton X-100, $2.5 \mathrm{mM}$ sodium pyrophosphate, $1 \mathrm{mM} \beta$-glycerophosphate, $1 \mathrm{mM} \mathrm{Na} 3 \mathrm{VO}_{4}, 1 \mu \mathrm{g} / \mathrm{mL}$ leupeptin and $1 \mathrm{mM}$ phenylmethylsulfonyl fluoride for $30 \mathrm{~min}$ on ice followed by brief sonication. Cell lysates were centrifuged and the supernatant was either resuspended in a loading buffer $(50 \mathrm{mM}$ Tris-HCl, pH 6.8, 2\% sodium dodecyl sulfate (SDS), $200 \mathrm{mM}$ dithiothreitol, $20 \%$ glycerol and $0.2 \%$ bromphenol blue) or used for immunoprecipitation. For immunoprecipitation, $1 \mu \mathrm{g}$ of anti-FAK (C20) polyclonal antibody was added to cell lysates $\left(2 \times 10^{6}\right.$ cells). After $4 \mathrm{~h}$ of incubation at $4 \mathrm{C}$, protein $\mathrm{G}$ sepharose beads $(20 \mu \mathrm{L})$ were added to precipitate total FAK. The precipitates were washed three times and specific bound proteins were electrophoresed on an SDS-polyacrylamide gel electrophoresis and transferred to a nitrocellulose membrane as previously described (Huang et al. 2006). The membranes were incubated with anti-FAK pY397 and pY576 polyclonal antibody (Biosources, Nivelles, Belgium); anti-FAK polyclonal antibody (C-20, Santa Cruz Biotechnology, CA); anti-phosphopaxillin (Tyr 118; BD Transduction Lab, Heidelberg, Germany); anti-paxillin polyclonal antibody (Transduction Lab); rabbit anti-phospho-MAPK (New England Biolabs, Inc., MA); and anti-vinculin monoclonal antibody (Sigma), then incubated with horseradish peroxidaseconjugated anti-rabbit immunoglobulin $\mathrm{G}$ ( $\mathrm{IgG}$ ) or anti-mouse IgG (Santa Cruz Biotechnology, CA). The signals were visualized with enhanced chemilumescence (ECL) reagents (Amersham Biosciences, Buckinghamshire, UK).

\section{Statistical Analysis}

Student's $t$-test was used for statistical analyses. All experiments were repeated at least three times. Data are presented as means \pm SD. $P<0.05$ was considered significant. 


\section{RESULTS}

\section{Ammonium Hydroxide Extracts of Black Tea Inhibit Growth of Colon Cancer Cells}

To investigate the effect of black tea extracts on cancer cell growth, we analyzed cells by trypan blue exclusion assays after treatment of colon cancer cells with various concentrations of mock or black tea extracts for $48 \mathrm{~h}$. To know if the effects on cell growth are not restricted to one cell line, we used two colon cancer cell lines, SW480 and HCT116. We found that the 50\% inhibitory concentration $\left(\mathrm{IC}_{50}\right)$ of the black tea extracts for SW480 and HCT116 cells were $96.4 \mu \mathrm{g} / \mathrm{mL}$ and $75 \mu \mathrm{g} / \mathrm{mL}$, respectively. We therefore chose the concentration below or above the $\mathrm{IC}_{50}$ for experiments. After the 48-h treatment with $25 \mu \mathrm{g} / \mathrm{mL}$ and $125 \mu \mathrm{g} / \mathrm{mL}$ black tea extracts, we observed that cell growth of SW480 cells grown at 10\% FBS were suppressed by $35 \%$ and $56 \%$, respectively, compared with their corresponding mock-treated cells (Fig. 1a, left panel). Cell growth of HCT116 cells treated with $25 \mu \mathrm{g} / \mathrm{mL}$ and $125 \mu \mathrm{g} / \mathrm{mL}$ black tea extracts were suppressed by $41 \%$ and $59 \%$, respectively (Fig. 1a, right panel). Under serum-free conditions, cell growth of SW480 cells treated with $25 \mu \mathrm{g} / \mathrm{mL}$ and $125 \mu \mathrm{g} / \mathrm{mL}$ black tea extracts were suppressed by $22 \%$ and $55 \%$, respectively (Fig. 1b, left panel). In addition, cell growth of HCT116 cells treated with $25 \mu \mathrm{g} / \mathrm{mL}$ and $125 \mu \mathrm{g} / \mathrm{mL}$ black tea extracts were suppressed by $26 \%$ and $36 \%$, respectively (Fig. 1b, right panel). These results suggested that the ammonium hydroxide extracts of black tea can significantly inhibit the growth of colon cancer cells in a dose-dependent manner in vitro under $10 \%$ serum and serum-free conditions.

\section{Ammonium Hydroxide Extracts of Black Tea Cause Cell Death}

To investigate whether the decreased cell growth is due to an increase in cell death, we performed flow cytometry of $70 \%$ ethanol-fixed cells with propidium iodide, a fluorescent dye that binds to DNA, as described previously (Wang et al. 2001). A hallmark of apoptotic cell death is the cleavage of chromosomal DNA by endonucleases activated by the caspase cascade. The degradation of apoptotic cells results in a decrease in total DNA content to a level that is lower than the DNA content of cells in the G1 phase. Consequently, the DNA content of apoptotic cells appears in a DNA content profile as a peak below the DNA content of cells in G1 phase. We found that the population of subG1 cells of SW480 and HCT116 cells treated with $25 \mu \mathrm{g} / \mathrm{mL}$ black tea extracts for $48 \mathrm{~h}$ were $44 \%$ and $53 \%$, respectively (Fig. 2). In contrast, only $6.3 \%$ and $16.3 \%$ of subG1 cells were detected for mock-treated SW480 and HCT116 cells, respectively. These data indicate that black tea extracts can significantly cause cell death in colon cancer cells. 

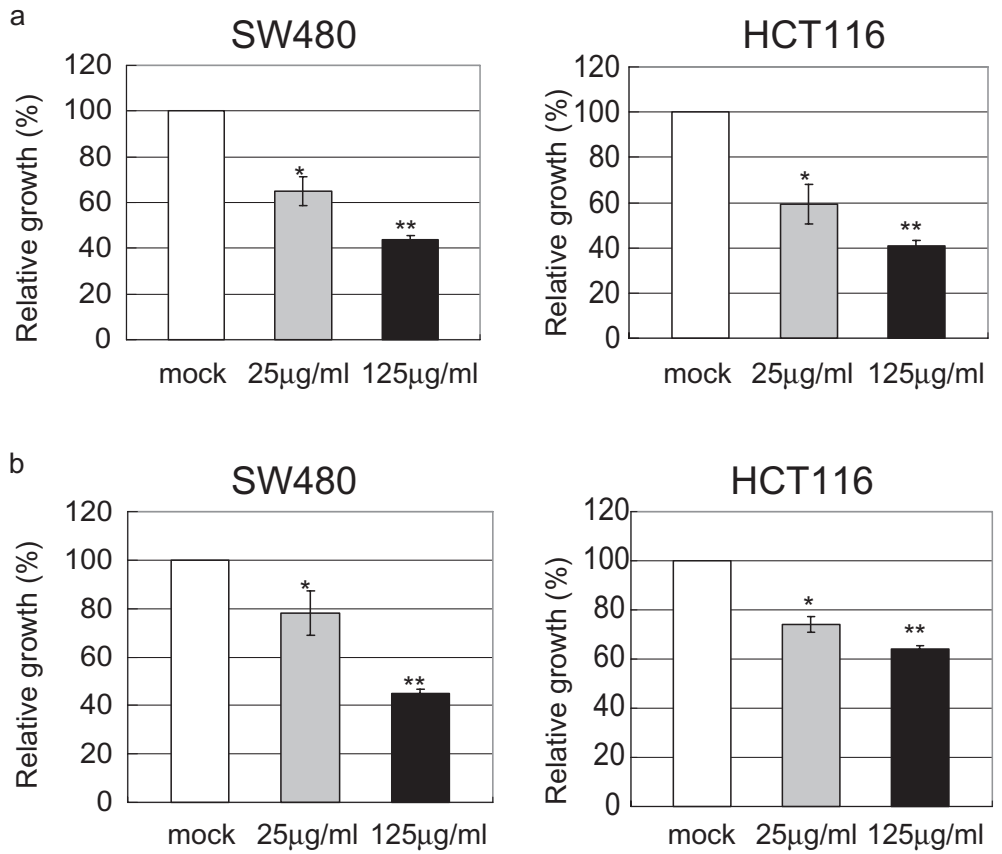

FIG. 1. AMMONIUM HYDROXIDE EXTRACTS OF BLACK TEA INHIBIT GROWTH OF CANCER CELLS

Colon cancer cell lines SW480 and HCT116 were grown in six-well plates at $30 \%$ confluence and treated with mock (white bars), $25 \mu \mathrm{g} / \mathrm{mL}$ (grey bars) and $125 \mu \mathrm{g} / \mathrm{mL}$ (black bars) black tea extracts under $10 \%$ fetal bovine serum (a) or serum-free (b) conditions. After $48 \mathrm{~h}$ treatment, cell numbers were counted and the relative growth to the mock-treated cells was shown. Data are presented as means \pm standard deviation from three independent experiments. ${ }^{*} P<0.05$ compared with mock treatment; ** $P<0.05$ compared with $25 \mu \mathrm{g} / \mathrm{mL}$ treatment.

To further know whether the cell death caused by black tea extract is through apoptosis, we analyzed cells by flow cytometry with annexin $\mathrm{V}$ and propidium iodide (PI). Under 10\% FBS or serum-free conditions, we did not find significant amounts of annexin V-positive/PI-negative cells, which indicate early apoptotic cells (not shown). These results suggested that the cell death induced by black tea extract was mainly nonapoptotic cell death.

\section{Ammonium Hydroxide Extracts of Black Tea Inhibit Cell Migration}

The effect of black tea extracts on cancer cell migration was assessed by a monolayer wound-healing assay. As shown in Fig. 3a, migration rates of SW480 and HCT116 cells treated with $25 \mu \mathrm{g} / \mathrm{mL}$ black tea extracts decreased by $53 \%$ and $64 \%$, respectively, compared with mock-treated cells. The SW480 
a
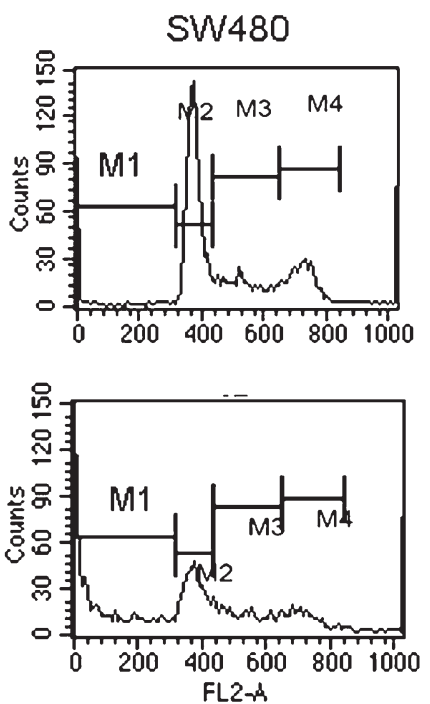
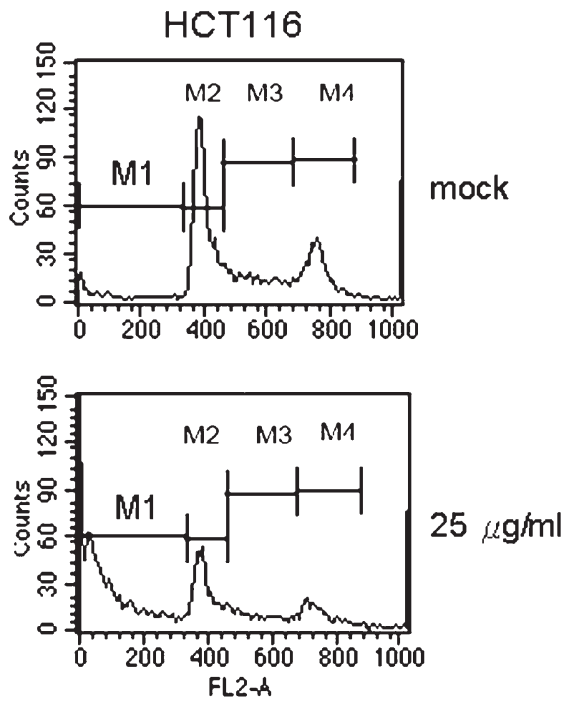

b

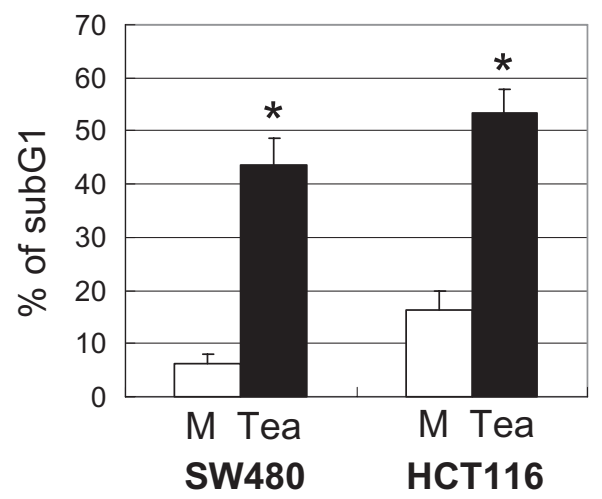

FIG. 2. AMMONIUM HYDROXIDE EXTRACTS OF BLACK TEA CAUSE CELL DEATH

(a) SW480 and HCT116 cells treated with mock or $25 \mu \mathrm{g} / \mathrm{mL}$ black tea extracts for $48 \mathrm{~h}$ were analyzed by flow cytometry with propidium iodide staining. The gated areas M1 indicate the subG1 population, which are dead cells. (b) Percentage of subG1 population was presented. SW480 and HCT116 cells were treated with mock (M) or $25 \mu \mathrm{g} / \mathrm{mL}$ black tea extracts (Tea). Data are presented as means \pm standard deviation from three independent experiments. $* P<0.05$ compared with mock treatment.

and HCT116 cells treated with $125 \mu \mathrm{g} / \mathrm{mL}$ black tea extracts showed a decrease by $89 \%$ and $94 \%$, respectively. Under serum-free conditions, migration rates of SW480 and HCT116 cells were also significantly inhibited by black tea extract (Fig. 3b). In addition, this effect was dose-dependent. These 

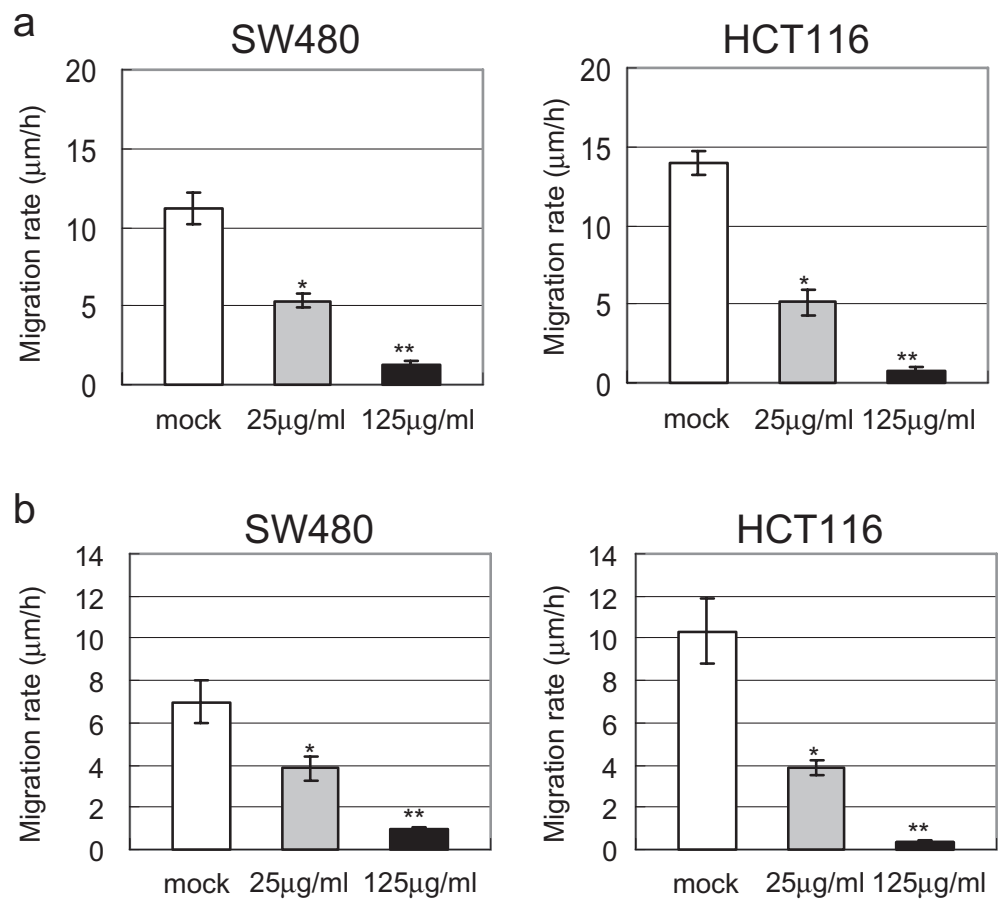

FIG. 3. AMMONIUM HYDROXIDE EXTRACTS OF BLACK TEA INHIBIT CANCER CELL MIGRATION

Cell migration of SW480 and HCT116 cells treated with various concentrations of black tea extracts for $48 \mathrm{~h}$ was analyzed by wound healing assays under $10 \%$ fetal bovine serum (a) or serum-free (b) conditions. The migration rate was calculated as migration distance $(\mu \mathrm{m}) /$ time $(\mathrm{h})$. Data are presented as means \pm standard deviation from three independent experiments. $* P<0.05$ compared with mock treatment; ** $P<0.05$ compared with $25 \mu \mathrm{g} / \mathrm{mL}$ treatment.

data suggested that the ammonium hydroxide extracts from black tea significantly decreased the motility of colon cancer cells under 10\% FBS and serumfree conditions.

\section{Ammonium Hydroxide Extracts of Black Tea Inhibit Cell Invasion}

Tumor cell invasion is a critical process in cancer metastasis, which involves cell attachment to the extracellular matrix (ECM), localized degradation of the ECM and cell migration through the tissue barrier (Liotta and Stetler-Stevenson 1991). To investigate the effect of black tea extracts on the invasion of colon cancer, we performed a Matrigel invasion assay, which mimics active transmigration of cancer cells across a reconstituted basement 


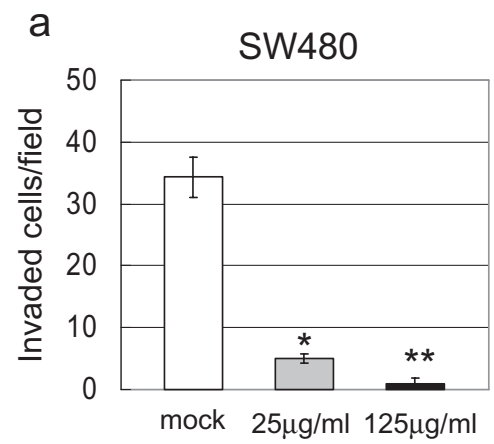

b

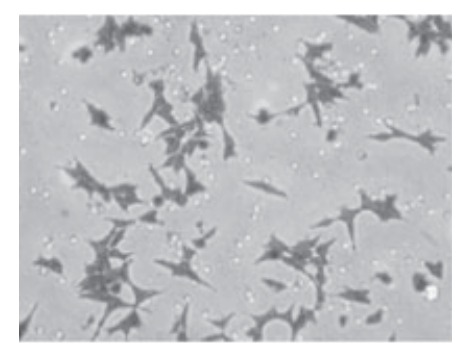

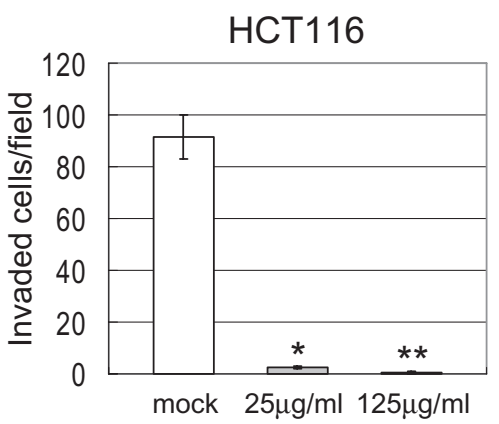

C

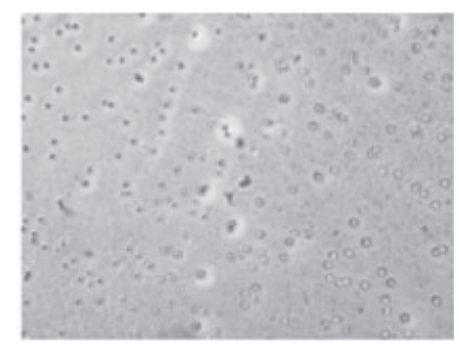

FIG. 4. AMMONIUM HYDROXIDE EXTRACTS OF BLACK TEA BLOCK CANCER CELL INVASION

(a) Cell invasion assays were analyzed by Matrigel invasion assays. SW480 (left panel) and HCT116 cells (right panel) were seeded in each chamber and treated with mock (white bars), $25 \mu \mathrm{g} / \mathrm{mL}$ (grey bars) or $125 \mu \mathrm{g} / \mathrm{mL}$ (black bars) black tea extracts. After $48 \mathrm{~h}$, the invaded cells were stained by crystal violet and then counted under microscope. Data are presented as means \pm standard deviation from three independent experiments. $* P<0.05$ compared with mock

treatment; ** $P<0.05$ compared with $25 \mu \mathrm{g} / \mathrm{ml}$ black tea extract treatment. (b) and (c) The representative images of invaded HCT116 cells treated with mock (b) or $25 \mu \mathrm{g} / \mathrm{mL}$ tea extracts (c) were shown. $200 \times$ magnification.

membrane. Invaded numbers of SW480 and HCT116 cells treated with $25 \mu \mathrm{g} / \mathrm{mL}$ black tea extracts were decreased by $85 \%$ and $97 \%$, respectively (Fig. 4). SW480 and HCT116 cells treated with $125 \mu \mathrm{g} / \mathrm{mL}$ black tea extracts showed a decrease in invading cell numbers by $97 \%$ and $99 \%$, respectively. These data showed that the ammonium hydroxide extracts from black tea can significantly block cancer cell invasion as determined by Matrigel invasion assays.

\section{Ammonium Hydroxide Extracts from Black Tea Inhibit Tyrosine Phosphorylation of FAK and Paxillin}

FAK and paxillin play a key role in integrin-mediated signalings which control cell adhesion, migration and invasion. We found that tyrosine 
a

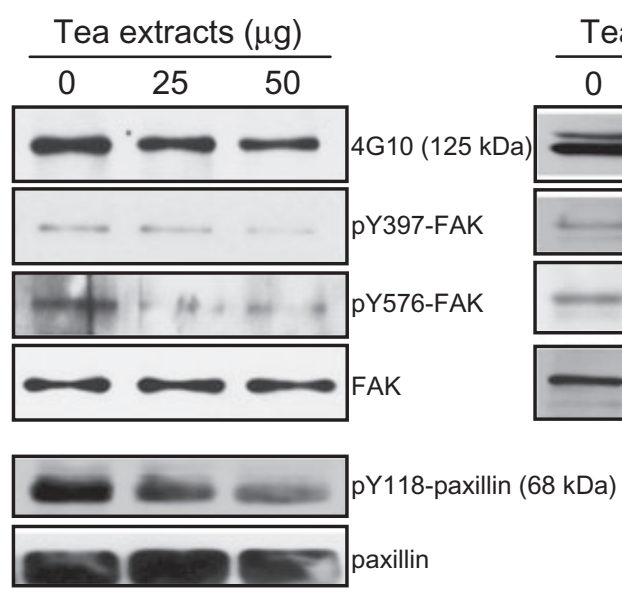

b

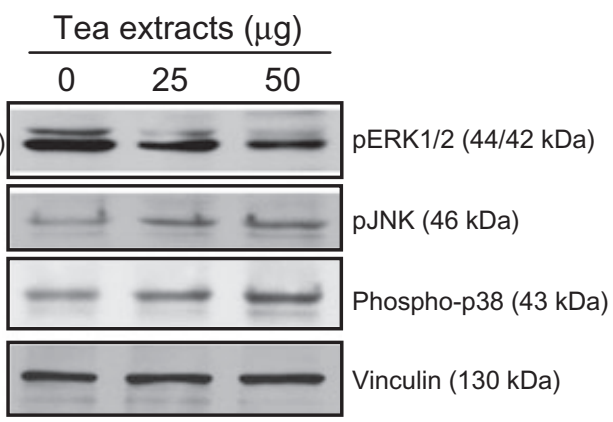

FIG. 5. AMMONIUM HYDROXIDE EXTRACTS FROM BLACK TEA REGULATE TYROSINE 5. PHOSPHORYLATION OF FAK AND PAXILLIN, AS WELL AS MAPK PHOSPHORYLATION

(a) Ammonium hydroxide extracts from black tea regulate phosphorylation of FAK and paxillin. The phosphorylation of FAK and paxillin were analyzed by immuno-blotting using HCT116 cells treated with $25 \mu \mathrm{g} / \mathrm{mL}$ or $50 \mu \mathrm{g} / \mathrm{mL}$ of black tea extracts as indicated for $48 \mathrm{~h}$. In the upper panel,

the same amount of cell extracts was immunoprecipitated with anti-FAK (C20) and then immunoblotted with 4G10, anti-FAK pY397, pY576 or anti-FAK antibody. In the lower panel, the same amount of cell extracts was immunoblotted with anti-paxillin pY118 or anti-paxillin antibody.

(b) Ammonium hydroxide extracts from black tea regulate MAPK signaling. Effects of black tea extracts on MAPK phosphorylation were analyzed by Western blotting. The same amount of HCT116 cell extracts was immunoblotted with anti-pERK1/2, -pJNK or phospho-p38. Vinculin was used as an internal control. Molecular weights of analyzed proteins are as indicated.

FAK, focal adhesion kinase; MAPK, mitogen-activated protein kinase; pERK, phosphorylated extracellular signal-regulated kinase; pJNK, phosphorylated c-Jun N-terminal kinase.

phosphorylation of FAK was significantly inhibited by the tea extracts in a dose-dependent manner as detected by 4G10 monoclonal antibody (Fig. 5, left panel). In addition, tyrosine phosphorylation of FAK pY397 and pY576 was also decreased. In contrast, the expression levels of FAK were not significantly affected. We also found that tyrosine phosphorylation of paxillin Y118 was inhibited by the tea extracts in a dose-dependent manner (Fig. 5, left panel), whereas there were no significant changes in total amounts of paxillin. These data suggested that ammonium hydroxide extracts from black tea can inhibit tyrosine phosphorylation of both FAK and paxillin. 


\section{Ammonium Hydroxide Extracts from Black Tea Regulate MAPK Signaling}

Since MAPK signaling pathways have been demonstrated to regulate cell survival and migration, we investigated the effects of tea extracts on the phosphorylation of three MAPKs: ERK, p38 and JNK. As shown in Fig. 5 (right panel), phosphorylation of ERK1/2 was significantly inhibited by the tea extracts in a dose-dependent manner. In contrast, p38 and JNK showed an increase in the phosphorylation levels. Vinculin, a cytoskeletal protein, was used as a control and its expression levels were not affected by the tea extracts. These data suggested that the tea extracts can also regulate MAPK signaling pathways.

\section{DISCUSSION}

This is the first study on the anticancer activities of crude ammonium hydroxide extracts from black tea. The significance of this finding is to provide the industry an economical way to make use of black tea leaves for development of anticancer drugs after making tea drink. We demonstrated that the ammonium hydroxide extracts of black tea can significantly inhibit cell growth, migration and invasion of colon cancer cell lines SW480 and HCT116 in vitro, which are established from Dukes' type B and type C colon tumor, respectively. We found that the cell death caused by ammonium hydroxide extracts is not via apoptotic cell death. The possible process of cell death caused by black tea extracts is still open, which includes necrosis and autophagy. It will be interesting to investigate further the effects of black tea extracts on colon tumor growth and metastasis in vivo.

In addition to the growth inhibitory effect, we found that the tea extracts can block cell migration and invasion. This raises a question whether the decrease in cell migration and invasion is due to the growth inhibitory effect of black tea extracts. We found that $25 \mu \mathrm{g} / \mathrm{mL}$ black tea extracts inhibited SW480 and HCT116 cell growth by $35 \%$ and $41 \%$, respectively. However, migration rates of SW480 and HCT116 were decreased by $52.7 \%$ and $63.3 \%$, respectively. Invading cell numbers of SW480 and HCT116 were decreased by $85.3 \%$ and $97.5 \%$, respectively. These data suggest that the decrease in the migration rate and invading ability of colon cancer cells does not simply result from the cell death. Instead, the extracts can inhibit cancer cell migration and invasion via other mechanisms in addition to cell death.

Cell-ECM interactions regulate cancer cell behavior during tumor progression. The integrins have been demonstrated to be the cell surface receptors for ECM and mediate cell migration and invasion during metastasis (Guo and 
Giancotti 2004). FAK and paxillin are important downstream signaling molecules of most integrins (Playford and Schaller 2004). Here we found that black tea extracts can inhibit cell migration and invasion, and downregulate tyrosine phosphorylation of both FAK and paxillin. In addition, we found that the cell migration rate of SW480 and HCT116 cells can be inhibited by black tea extracts under serum-free conditions. These results suggest that integrin signaling pathways could be involved in the inhibitory effects of black tea extracts on cell migration and invasion.

Recent studies have demonstrated that MAPKs, including JNK, p38 and ERK, play important roles in cell migration (Huang et al. 2004). Raf-methyl ethyl ketone-ERK signaling plays a central role in control of cell survival and growth (Sebolt-Leopold and Herrera 2004). Also, activation of JNK1/ JNK2 and p38 are connected to stress-activated apoptosis (Wada and Penninger 2004). However, the effects of black tea extracts on MAPK signaling are poorly understood. It has been found that epigallocatechin-3gallate - the major polyphenol present in green tea - and TF - the major polyphenol present in black tea - can increase ERK1/2 in prostate cancer cells DU145 and LNCaP (Siddiqui et al. 2004a). In contrast, our results showed that ammonium hydroxide extracts of black tea inhibited phosphorylation of ERK in colon cancer cell line HCT116. These data suggest that the major effective components in ammonium hydroxide extracts of black tea are different from TF or that the differential effects of black tea extracts on ERK could be resulted from different cellular backgrounds of prostate and colon cancer cell lines. Black tea polyphenols were found to activate endothelial nitric-oxide synthase via activation of p38 MAPK (Anter et al. 2004). Consistent with this finding, we found that the ammonium hydroxide extracts of black tea increased phosphorylation of p38 MAPK in colon cancer cells. Although the molecular mechanism by which the ammonium hydroxide extracts of black tea inhibit colon cancer cell survival, migration and invasion is still not resolved, we suggest that the MAPK signaling pathways could be involved.

Several tea extracts and their polyphenol derivatives have been suggested to be used for cardiovascular and neurodegenerative diseases, obesity and cancer therapy (Weinreb et al. 2004; Koo and Cho 2004; Siddiqui et al. 2004b; Scalbert et al. 2005). In the present data, we showed that ammonium hydroxide extracts of black tea are able to decrease cell survival, migration and invasion. Interestingly, the extracts can decrease pERK, but increase phosphop38 and pJNK in colon cancer cells, indicating that the ammonium hydroxide extracts of black tea exhibit unique activities in terms of MAPK signaling. In addition, activities of FAK and paxillin are inhibited by the tea extracts, demonstrating that integrin signaling is affected by the tea extracts. It will be of great interest to study further on the biological activities of black tea extracts 
and to apply the gained information for cancer therapy and other human diseases which are regulated by integrin and/or MAPK signaling pathways.

\section{ACKNOWLEDGMENTS}

This study was supported by the National Health Research Institute Grant NHRI-EX95-9410BC and PRIT Biotech Co., Ltd.

\section{REFERENCES}

ANTER, E., THOMAS, S.R., SCHULZ, E., SHAPIRA, O.M., VITA, J.A. and KEANEY, J.F. JR. 2004. Activation of endothelial nitric-oxide synthase by the p38 MAPK in response to black tea polyphenols. J. Biol. Chem. 279, 46637-46643.

BALENTINE, D., WISEMAN, S.A. and BOUWENS, L.C.M. 1997. The chemistry of tea flavonoids. Crit. Rev. Food Sci. Nutr. 37, 693-704.

GUO, W. and GIANCOTTI, F.G. 2004. Nat. Rev. Mol. Cell Biol. 5, 816-826. HASLAM, E. 2003. Thoughts on thearubigins. Phytochemistry 64, 61-73.

HUANG, C., JACOBSON, K. and SCHALLER, M.D. 2004. MAP kinases and cell migration. J. Cell Sci. 117(Pt 20), 4619-4628.

HUANG, M.C., CHEN, H.Y., HUANG, H.C., HUANG, J., LIANG, J.T., SHEN, T.L., LIN, N.Y., HO, C.C., CHO, I.M. and HSU, S.M. 2006. C2GnT-M is downregulated in colorectal cancer and its re-expression causes growth inhibition of colon cancer cells. Oncogene 25, 3267-3276.

HUNG, Y.C., SAVA, V.M., JUANG, C.L., YEH, T., SHEN, W.C. and HUANG, G.S. 2002. Gastrointestinal enhancement of MRI with melanin derived from tea leaves (Thea sinensis Linn). J. Ethnopharmacol. 79, 75-79.

HUNG, Y.C., SAVA, V.M., BLAGODARSKY, V.A., HONG, M.Y. and HUANG, G.S. 2003. Protection of tea melanin on hydrazine-induced liver injury. Life Sci. 72, 1061-1071.

ISEMURA, M., SAEKI, K., KIMURA, T., HAYAKAWA, S., MINAMI, T. and SAZUKA, M. 2000. Tea catechins and related polyphenols as anticancer agents. Biofactors 13(1-4), 81-85.

KOO, M.W. and CHO, C.H. 2004. Pharmacological effects of green tea on the gastrointestinal system. Eur. J. Pharmacol. 500(1-3), 177-185.

LAMBERT, J.D., HONG, J., YANG, G.Y., LIAO, J. and YANG, C.S. 2005. Inhibition of carcinogenesis by polyphenols: evidence from laboratory investigations. Am. J. Clin. Nutr. 81, 284S-291S. 
LIN, Y.S., TSAI, Y.J., TSAY, J.S. and LIN, J.K. 2003. Factors affecting the levels of tea polyphenols and caffeine in tea leaves. J. Agric. Food Chem. 51, 1864-1873.

LIOTTA, L.A. and STETLER-STEVENSON, W.G. 1991. Tumor invasion and metastasis: An imbalance of positive and negative regulation. Cancer Res. 51(Suppl. 18), 5054s-5059s.

PLAYFORD, M.P. and SCHALLER, M.D. 2004. Oncogene 23, 7928-7946.

SCALBERT, A., MANACH, C., MORAND, C., REMESY, C. and JIMENEZ, L. 2005. Dietary polyphenols and the prevention of diseases. Crit. Rev. Food Sci. Nutr. 45, 287-306.

SEBOLT-LEOPOLD, J.S. and HERRERA, R. 2004. Targeting the mitogenactivated protein kinase cascade to treat cancer. Nat. Rev. Cancer 4, 937-947.

SIDDIQUI, I.A., ADHAMI, V.M., AFAQ, F., AHMAD, N. and MUKHTAR, H. 2004a. Modulation of phosphatidylinositol-3-kinase/protein kinase Band mitogen-activated protein kinase-pathways by tea polyphenols in human prostate cancer cells. J. Cell. Biochem. 91, 232-242.

SIDDIQUI, I.A., AFAQ, F., ADHAMI, V.M., AHMAD, N. and MUKHTAR, H. 2004b. Antioxidants of the beverage tea in promotion of human health. Antioxid. Redox. Signal. 6, 571-582.

WADA, T. and PENNINGER, J.M. 2004. Mitogen-activated protein kinases in apoptosis regulation. Oncogene 23, 2838-2849.

WANG, N.S., UNKILA, M.T., REINEKS, E.Z. and DISTELHORST, C.W. 2001. Transient expression of wild-type or mitochondrially targeted Bcl-2 induces apoptosis, whereas transient expression of endoplasmic reticulum-targeted $\mathrm{Bcl}-2$ is protective against Bax-induced cell death. J. Biol. Chem. 276, 44117-44128.

WEI, H., ZHANG, X., ZHAO, J.F., WANG, Z.Y., BICKERS, D. and LEBWOHL, M. 1999. Scavenging of hydrogen peroxide and inhibition of ultraviolet light-induced oxidative DNA damage by aqueous extracts from green and black teas. Free Radic. Biol. Med. 26, 1427-1435.

WEINREB, O., MANDEL, S., AMIT, T. and YOUDIM, M.B. 2004. Neurological mechanisms of green tea polyphenols in Alzheimer's and Parkinson's diseases. J. Nutr. Biochem. 15, 506-516. 